\title{
HUBUNGAN KECEMBURUAN DENGAN KUALITAS HUBUNGAN ROMANTIS REMAJA PENGGUNA INSTAGRAM USIA 15-18 TAHUN YANG BERPACARAN
}

\author{
Reti Dwi Utami ${ }^{1}$, Langgersari Elsari Novianti ${ }^{2}$ \\ ${ }^{1}$ Fakultas Psikologi Universitas Padjadjaran \\ ${ }^{2}$ Fakultas Psikologi Universitas Padjadjaran \\ reti14001@mail.unpad.ac.id
}

\begin{abstract}
ABSTRAK
Instagram bukan hanya menjadi media untuk mendapatkan informasi mengenai pasangan tetapi juga dapat menimbulkan kecemburuan bagi para remaja. Kecemburuan seringkali diasosiasikan dengan hal yang negatif pada sebuah hubungan romantis. Penelitian ini bertujuan untuk melihat hubungan antara kecemburuan dengan kualitas hubungan romantis pada remaja pengguna instagram usia 15-18 tahun yang berpacaran. Alat ukur yang digunakan untuk mengukur kecemburuan merupakan hasil adaptasi dan modifikasi alat ukur multidimensional jealousy dari Pfeiffer \& Wong (1989) dengan reliabilitas sebesar 0.950. Kualitas hubungan romantis diukur dengan menggunakan alat ukur PBSC dan SBSC dari Ducat \& Zimmer-Gembeck (2010) yang sudah diadaptasi oleh Sarrah (2015) berdasarkan self determination theory (SDT) dengan reliabilitas sebesar 0.923 . Kedua alat ukur ini memiliki bukti validitas berupa evidence based in test content. Responden penelitian ini berjumlah 108 remaja pengguna instagram berusia 15-18 tahun yang berpacaran. Melalui teknik statistik pearson correlation didapatkan hasil bahwa hubungan kecemburuan dengan kualitas hubungan romantis remaja pengguna instagram usia 15-18 tahun yang berpacaran adalah sebesar -0.291 dengan $p<0.01$. Semakin tinggi kecemburuan yang dimiliki remaja maka semakin rendah kualitas hubungan romantis yang dimilikinya.
\end{abstract}

Kata kunci: kecemburuan, kualitas hubungan romantis, remaja pengguna instagram, remaja usia 15-18 tahun.

\section{CORRELATION BETWEEN JEALOUSY AND ROMANTIC RELATIONSHIP QUALITY AMONG 15-TO-18- YEAR-OLD ADOLESCENT INSTAGRAM USERS WHO ARE DATING}

\begin{abstract}
Instagram was one of the most used social media by adolescent nowdays. Adolescent could get a lot of information about his/her partner in instagram. But, sometimes this information could trigger jealousy for them. Jealousy was often associated with negative outcomes in romantic relationship. This research was conducted to find the correlation between jealousy and romantic relationship quality among 15-to-18-yearsold adolescent instagram users who are dating. This research was used correlational method to see the correlation between jealousy and romantic relationship quality. Jealousy was measured using an instrument named multidimensional jealousy scale by Pfeiffer \& Wong (1989) which has been adapted and modified with reliability 0.950. Romantic relationship quality was measured using an instrument named Partner Behaviour as Social Context (PBSC) and Self Behaviour as Social Context (SBSC) by Ducat \& Zimmer-Gembeck (2010) which has been adapted by Sarrah (2015) with reliability 0.923. Both of them was using evidence based on test content as validity testing. The total number of participants was 108 15-to-18years-old adolescent instagram users who are dating. The Pearson Correlation was used and the result showed that the correlation between jealousy and romantic relationship quality was, $r=-0.291, p<0.01$. This indicated negative significant correlation between jealousy and romantic relationship quality.
\end{abstract}

Keywords: jealousy, romantic relationship quality, 15-to-18-years-old adolescent, adolescent instagram users. 


\section{Journal of Psychological Science and Profesion (JPSP)}

Vol.2, No.1, April 2018

E-mail: jurnal.psp@unpad.ac.id

\section{PENDAHULUAN}

Perkembangan teknologi saat ini semakin pesat. Salah satu perkembangan teknologi yang semakin terlihat adalah Social Networking Sites (SNS). SNS dapat digunakan untuk menjalin hubungan baru maupun menjaga hubungan yang sudah ada, salah satunya adalah pada hubungan romantis. SNS dapat digunakan untuk mengekspresikan hubungan romantisnya. llustrasi yang paling jelas terlihat dari hubungan romantis dapat ditemukan melalui profile picture (Bowe, 2010; Mansson \& Myers, 2011; Papp, Danielewicz, \& Cayemberg, 2012; Utz \& Beukeboom, 2011, dalam Farrugia 2013). Secara umum, ini berarti pasangan ingin menunjukkan hubungan mereka dengan memperlihatkan dirinya dan pasangan dalam sebuah foto yang dijadikan foto profil atau pada halaman utama profil (Farrugia, 2013).

Ternyata SNS tidak hanya memiliki efek positif terhadap suatu hubungan romantis, tetapi juga menjadi salah satu sumber dari perasaan cemburu kepada pasangan. Hal ini karena SNS yang bersifat terbuka dan dapat diakses dengan mudah serta menyediakan berbagai informasi tentang pasangan. Individu dapat melihat aktivitas yang dilakukan oleh pasangannya di SNS, selain itu juga bisa melihat interaksi pasangan dengan lawan jenis, yang dapat menjadi salah satu sumber dari kecemburuan. Beberapa penelitian mengenai kecemburuan pada SNS telah dilakukan. Salah satunya adalah Muise, Christofides \& Desmarais (2009) mengatakan bahwa efek negatif dari penggunaan Facebook adalah meningkatnya kecemburuan. Muise, et al, (2009) menunjukkan bahwa seseorang dapat menjadi cemburu jika mereka melihat pasangannya berinteraksi dengan orang lain yang berpotensi menjadi ancaman bagi hubungannya di Facebook.

Menurut White (1980) kecemburuan merupakan pikiran, emosi dan tindakan kompleks yang berasal dari kehilangan atau ancaman pada self-esteem dan/atau keberlangsungan atau kualitas dari hubungan romantis. White juga menjelaskan bahwa kecemburuan terdiri dari tiga komponen yaitu kognitif, emosi, dan perilaku. Pfeiffer dan Wong (1989) kemudian mengembangkan konsep tersebut dengan menambahkan bahwa ketiga kompenen ini tidak selalu saling mengikuti, tetapi dapat terjadi secara simultan dan dapat saling berinteraksi satu sama lain. Komponen kognitif menekankan pada kekhawatiran dan kecurigaan yang paranoid seseorang akan ketidaksetiaan pasangannya. Komponen emosi yang ditunjukkan misalnya dengan perasaan marah, ketakutan, atau sedih. Kecemburuan emosi bisa terjadi karena adanya penilaian kognitif, tetapi juga bisa terjadi karena respon pada stimulus tertentu. Komponen perilaku ditunjukkan dengan perilaku detektif atau protektif yang dilakukan seseorang ketika mempersepsikan adanya lawan, baik nyata ataupun tidak.

Secara umum, kecemburuan diasosiasikan dengan hasil hubungan yang negatif, seperti konflik, kekerasan, dan perceraian (Barnett, Martinez, \& Bluestein, 1995; Buss, 2000; Puente \& Cohen, 2003 dalam Barelds \& Barelds-Dijkstra, 2007). Beberapa peneliti berpendapat bahwa kecemburuan merupakan fenomena hubungan yang negatif dan dapat disertai dengan kualitas hubungan yang rendah. Kecemburuan tidak hanya berkontribusi pada konflik dan insecurity, tetapi juga menyebabkan pasangan non-jealous merasa tidak dipercaya dan dikontrol. Selain itu, kualitas hubungan dapat berhubungan secara negatif dengan kecemburuan karena individu yang tidak bahagia akan lebih banyak memiliki extra-dyadic affairs dan sebagai konsekuensinya, memiliki pasangan yang lebih cemburu (Banfield \& McCabe, 2001; White, 1981 dalam Barelds \& Barelds-Dijkstra, 2007). Asosiasi negatif antara kecemburuan dan kualitas hubungan romantis telah diteliti oleh Andersen, Eloy, Guerrero, \& Spitzberg (1995), Barnett, et al. (1995), Buunk (1991) and Shackelford and Buss (2000).

Sementara pada penelitian Barelds \& Dijkstra (2006, dalam Barelds \& Barelds-Dijkstra, 2007) dan Buss (2000, dalam Barelds \& BareldsDijkstra, 2007) mengatakan bahwa kecemburuan setidaknya sebagian merupakan fenomena hubungan yang positif. Mereka berpendapat bahwa kecemburuan merupakan tanda bahwa pasangannya peduli terhadap satu sama lain dan menghargai hubungannya sebagai sesuatu yang harus ia lindungi (Barelds \& Barelds-Dijkstra, 2007). Penelitian lain yang mendukung hal tersebut adalah penelitian yang dilakukan oleh Mathes (1985, dalam Barelds \& Barelds-Dijkstra, 2007), ditemukan bahwa individu yang memiliki skor kecemburuan yang relatif tinggi memiliki hubungan yang lebih stabil dan sukses dibandingkan individu yang memiliki skor kecemburuan yang rendah.

Kualitas hubungan romantis menurut Collins (2003) merupakan persepsi individu terhadap sejauh mana hubungan yang sedang dijalani memberikan atau tidak memberikan manfaat melalui pengalaman dan interaksi. Menurut Ducat \& Zimmer-Gembeck (2010) kualitas hubungan romantis terdiri dari enam dimensi yaitu warmth, autonomy support, structure, rejection, coercion, dan chaos. Warmth, autonomy support, dan structure merupakan dimensi yang positif. Ketiga dimensi ini 


\section{Journal of Psychological Science and Profesion (JPSP)}

Vol.2, No.1, April 2018

E-mail: jurnal.psp@unpad.ac.id

menggambarkan perilaku pasangan yang positif. Misalnya warmth digambarkan dengan menyediakan kehangatan dan afeksi dalam memenuhi keterikatan, autonomy support digambarkan seperti membiarkan individu untuk mengembangkan pilihan dan tanggungjawab, dan structure digambarkan dengan sikap yang konsisten serta dapat diandalkan sehingga mendukung terpenuhinya kebutuhan kompetensi seseorang.

Sementara ketiga lainnya yaitu rejection, coercion, dan chaos merupakan perilaku yang negatif. Rejection digambarkan dengan perasaan benci, permusuhan dan mengabaikan pasangannya, coercion digambarkan dengan upaya mengendalikan pasangan secara berlebihan, menuntut, dan memberikan tekanan yang tinggi kepada pasangan. Chaos merupakan perilaku yang tidak konsisten, tidak menentu, dan tidak dapat dipercaya dari pasangan. Keenam dimensi ini akan menunjukkan apakah kualitas hubungan romantis seseorang itu positif atau negatif.

Penelitian sebelumnya terkait kecemburuan dan kualitas hubungan romantis lebih banyak pada kecemburuan di kehidupan nyata dan untuk media sosial lebih banyak meneliti pada Facebook. Pada penelitian ini peneliti tertarik untuk melihat kecemburuan pada Instagram. Instagram dipilih karena berdasarkan Press Release dari Masyarakat Telematika Indonesia \& Asosiasi Penyelenggara Jasa Internet Indonesia tahun 2017, Instagram merupakan media sosial yang paling sering digunakan di Indonesia. Instagram secara sederhana dapat didefinisikan sebagai aplikasi mobile berbasis iOS, Android dan Windows Phone dimana pengguna dapat membidik, meng-edit dan mem-posting foto atau video ke halaman utama Instagram dan jejaring sosial lainnya (Winarso, 2015)

Selain karena Instagram dapat membuat seseorang mendapatkan informasi mengenai aktivitas pasangannya. Instagram juga memfasilitasi seseorang untuk menjalin komunikasi yang bersifat pribadi. Komunikasi pasangan yang lebih bersifat privat dapat dilihat sebagai sesuatu yang lebih mencurigakan dan mengancam hubungan (Utz, Muscanell, \& Khalid 2015). Pada Instagram juga terdapat fitur seperti itu yaitu direct message dan closefriend, dimana seseorang dapat mengirimkan pesan langsung pada orang lain tanpa dapat dilihat oleh orang lain. Selain itu untuk akun yang di-private, seseorang yang tidak mem-follow akun tersebut tidak dapat melihat beberapa aktivitas yang dilakukannya di Instagram. Seperti misalnya ketika akun tersebut mem-posting foto, atau menandai seseorang pada fotonya. Hal ini juga dapat membuat seseorang merasa cemburu, ketika pasangannya berinteraksi atau menunjukkan hal yang mencurigakan dengan seseorang yang akunnya di-private.

Alasan lain mengapa penelitian ini berfokus pada Instagram adalah bahwa Instagram juga memungkinkan seseorang untuk melakukan monitoring behavior seperti pada Facebook. Pada Facebook, monitoring behavior ini berupa mengecek "top friends" atau halaman Facebook pasangan secara reguler (Utz, Muscanell, \& Khalid, 2015). Hal ini juga bisa terjadi pada Instagram, dimana seseorang dapat melihat atau membuka feeds Instagram pasangannya atau melihat apakah pasangannya memberikan tanda love atau mengomentari posting-an seseorang. Bahkan dengan fitur-fitur yang ada pada Instagram lebih memungkinkan hal tersebut terjadi. Dilihat dari bagaimana Facebook dapat menyebabkan kecemburuan, ternyata hal tersebut lebih banyak terdapat pada Instagram karena fitur yang lebih beragam yang memungkinkan seseorang melakukan lebih banyak aktivitas yang dianggap bisa menjadi ancaman bagi hubungannya.

Selain itu, penelitian mengenai kecemburuan dan kualitas hubungan romantis ini lebih sering dilakukan pada orang dewasa, namun jarang ditemukan pada remaja. Padahal fenomena hubungan romantis atau berpacaran tidak hanya terjadi pada masa dewasa saja. Pada remaja awal, hubungan pacaran dianggap sebagai sesuatu yang stressfull (Scanlan, 2012). Berbeda dengan remaja awal, pada usia remaja tengah remaja memiliki keinginan untuk berkencan, mempunyai rasa cinta yang mendalam kepada lawan jenis (Monks, Knoers \& Hadimoto, 2002).

Remaja tengah sendiri memiliki rentang usia 15-18 tahun (Monks, Knoers \& Hadimoto, 2002). Usia remaja yang semakin bertambah, membuat remaja akan semakin merasa diuntungkan, hubungan akan berjalan lebih lama dan pasangan akan memiliki peran yang lebih penting dalam kehidupan remaja. Mereka juga akan menghabiskan lebih banyak waktu dengan pasangan mereka dibandingkan dengan teman atau keluarga (Headspace, 2012), sehingga pada penelitian ini akan berfokus pada remaja tengah yang berpacaran.

Selain itu juga menurut Ducat \& ZimmerGembeck (2010), kualitas hubungan romantis memiliki hubungan yang positif dengan wellbeing remaja. Individu yang memiliki pasangan yang berperilaku lebih kritis, tidak selalu melakukan yang ia katakan, menunjukkan tanda ia tidak bergantung, dan/atau lebih sulit atau dengan kata lain remaja dengan kualitas hubungan romantis 


\section{Journal of Psychological Science and Profesion (JPSP)}

Vol.2, No.1, April 2018

E-mail: jurnal.psp@unpad.ac.id

yang rendah diprediksi memiliki life fulfillment yang rendah dan khususnya mengurangi psychological wellbeing-nya. Dilihat dari fenomena banyaknya remaja yang sudah berpacaran dan penggunaan Instagram saat ini, kemudian kecemburuan pada remaja yang terjadi pada Instagram dan bagaimana kecemburuan berhubungan dengan kualitas hubungan romantis, peneliti tertarik untuk meneliti hubungan kecemburuan dan kualitas hubungan romantis remaja pengguna Instagram usia 15-18 tahun yang berpacaran.

\section{METODE}

Penelitian ini merupakan penelitian kuantitatif non eksperimental dengan metode korelasional (Christensen, 2011). Populasi dari penelitian ini adalah remaja usia 15 - 18 tahun yang berpacaran minimal 6 bulan yang aktif menggunakan instagram. Karakteristik sampel penelitian ini antara lain remaja usia 15-18 tahun, berpacaran minimal 6 bulan, dan juga baik subjek maupun pasangannya merupakan pengguna aktif instagram yaitu yang mengakses instagram minimal 1 kali dalam sehari. Teknik sampling yang digunakan dalam penelitian ini adalah teknik nonprobability sampling yaitu convenience sampling. Jumlah sampel penelitian sebanyak 108 responden.

Pengukuran variabel kecemburuan dalam penelitian ini dilakukan dengan menggunakan alat ukur berbentuk kuesioner yang diadaptasi dan dimodifikasi dari alat ukur kecemburuan Pfeiffer dan Wong (1989) yang bernama multidimensional jealousy scale. Reliabilitas alat ukur kecemburuan hasil adaptasi ini adalah sebesar 0.950 . Kecemburuan dalam hal ini diukur dari 3 komponen kecemburuan yaitu kognitif, emosi, dan perilaku. Tipe skala yang digunakan adalah skala Likert.

Pengukuran variabel kualitas hubungan romantis dalam penelitian ini dilakukan dengan menggunakan alat ukur berbentuk kuesioner yang telah baku bernama Partner Behaviours as Social Context Scale (PBSC) dan Self Behaviour as Social Context (SBSC). Alat ukur ini dikembangkan oleh Ducat dan Zimmer-Gembeck (2010) berdasarkan Self Determination Theory. Berdasarkan SDT, dikembangkan enam dimensi dari kualitas hubungan romantis yaitu warmth, autonomy support, structure, rejection, coercion, dan chaos. Alat ukur ini telah diadaptasi ke dalam bahasa Indonesia oleh Sarrah Hasyim A.A pada penelitiannya tahun 2015 dengan reliabilitas sebesar 0.923. Alat ukur ini terdiri dari 30 item, pilihan jawaban untuk setiap itemnya menggunakan skala Likert dari sangat tidak setuju sampai ujung sangat setuju. Metode pengolahan data yang dilakukan dalam penelitian ini dengan menggunakan IBM SPSS Statistics 22 yaitu, statistika deskriptif, pearson correlation, independent sample $t$-test, dan one-way analysis of variance (ANOVA).

\section{HASIL DAN PEMBAHASAN}

Berdasarkan hasil perhitungan dengan menggunakan IBM SPSS Statistics 22 didapatkan hasil sebagai berikut:

Tabel 1. Gambaran Kategori Kecemburuan pada Remaja Pengguna Instagram Usia 15-18 Tahun yang Berpacaran

\begin{tabular}{cccc}
\hline Kategori & $\begin{array}{c}\text { Skor } \\
\text { Total }\end{array}$ & Jumlah & Persentasse \\
\hline Rendah & $24-96$ & 50 & $46.3 \%$ \\
\hline Tinggi & $97-168$ & 58 & $53.7 \%$ \\
\hline & Total & 108 & $100 \%$ \\
\hline
\end{tabular}

Hasilnya adalah sebanyak 50 responden (46.3\%) memiliki skor kecemburuan yang rendah dan sebanyak 58 orang (53.7\%) memiliki skor kecemburuan yang tinggi. Hal ini menunjukkan bahwa lebih banyak responden yang memiliki skor kecemburuan yang tinggi.

Individu yang memiliki tingkat kecemburuan yang tinggi artinya individu tersebut sering memiliki pemikiran atau kecurigaan remaja terhadap pasangannya di Instagram, merasakan perasaan sangat kesal ketika dihadapkan pada situasi yang menimbulkan kecemburuan di Instagram, serta sering melakukan perilaku detektif atau protektif kepada pasangannya di Instagram. Tingkat kecemburuan yang tinggi ini sejalan dengan yang dijelaskan oleh Persch (2007, dalam Utz \& Beukeboom, 2011) bahwa informasi yang ada dalam SNS dapat menstimulasi kecemburuan individu. Informasi dari Instagram sendiri kini semakin banyak yang bisa didapatkan oleh individu terkait pasangannya. Sehingga dengan informasi yang didapatkan di Instagram mengenai pasangan yang terkadang dapat membuatnya lebih cemburu.

Kecemburuan ini terdiri atas tiga komponen yaitu kognitif, emosi dan perilaku. Komponen yang memiliki jumlah responden terbanyak pada kategori tingginya adalah komponen emosi. Hal ini berarti mayoritas responden memiliki komponen emosi yang tinggi. Pfeiffer \& Wong (1989) komponen emosi merupakan reaksi emosional yang terjadi ketika adanya ancaman terhadap hubungan. Reaksi ini merupakan emosi negatif. Reaksi ini juga bisa muncul karena adanya penilaian kognitif terlebih dahulu tetapi dapat juga terjadi sebagai respon kondisional 


\section{Journal of Psychological Science and Profesion (JPSP)}

Vol.2, No.1, April 2018

E-mail: jurnal.psp@unpad.ac.id

pada stimulus tertentu. Mayoritas responden menjawab sangat kesal ketika dihadapkan pada situasi-situasi yang menimbulkan kecemburuan di Instagram. Sehingga komponen ini memiliki ratarata skor yang paling tinggi, serta mayoritas responden berada pada kategori tinggi.

Tabel 2. Gambaran Kategori Kualitas Hubungan Romantis Pada Remaja Pengguna Instagram Usia 15-18 Tahun yang Berpacaran

\begin{tabular}{cccc}
\hline Kategori & $\begin{array}{c}\text { Skor } \\
\text { Total }\end{array}$ & Jumlah & Persentasse \\
\hline Rendah & $60-210$ & 7 & $6 \%$ \\
Tinggi & $211-$ & 101 & $94 \%$ \\
\hline & 360 & & $100 \%$ \\
\hline
\end{tabular}

Berdasarkan tabel 2, dapat dilihat bahwa mayoritas responden yaitu sebanyak 101 orang (94\%) memiliki skor tinggi pada kualitas hubungan romantis. Sementara 7 orang lainnya (6\%) memiliki skor kualitas hubungan romantis yang rendah. Hal ini berarti mayoritas responden memiliki skor tinggi pada kualitas hubungan romantis.

Pada usia remaja tengah remaja memiliki keinginan untuk berkencan, mempunyai rasa cinta yang mendalam kepada lawan jenis (Monks, Knoers \& Hadimoto, 2002). Bertambahnya usia remaja akan membuat remaja semakin merasa diuntungkan, hubungan akan berjalan lebih lama dan pasangan akan memiliki peran yang lebih penting dalam kehidupan remaja. Mereka juga akan menghabiskan lebih banyak waktu dengan pasangan mereka dibandingkan dengan teman atau keluarga (Headspace, 2012). Rasa cinta yang mendalam kepada pasangannya serta peran pasangan yang lebih penting dalam kehidupannya maka ia merasa bahwa hubungan yang ia jalani memiliki manfaat untuk dirinya.

Individu dengan kualitas hubungan romantis yang tinggi akan merasa bahwa hubungan yang ia jalani bersama pasangannya memiliki manfaat untuk dirinya melalui pengalaman dan interaksi. Individu dengan kualitas hubungan romantis yang tinggi ini lebih banyak merasakan dirinya serta pasangannya saling menyediakan kehangatan dan afeksi, membiarkan pasangannya untuk mengembangkan pilihan dan tanggung jawab yang mendukung kebutuhan psikologis untuk mandiri, serta menjadi konsisten dan dapat diandalkan, juga mendukung dalam mengembangkan kompetensi pasangannya.

Sebaliknya, individu dengan kualitas hubungan romantis yang tinggi akan jarang bahkan tidak pernah merasa bahwa dirinya maupun pasangannya mengontrol, terlalu menuntut, dan memberikan tekanan kepada pasangan serta jarang atau bahkan tidak pernah merasa bahwa dirinya dan pasannya tidak konsisten, tidak menentu, dan tidak dapat dipercaya.

Pada variabel kualitas hubungan romantis, dimensi yang memiliki skor rata-rata paling tinggi adalah dimensi autonomy support. Hal ini berarti remaja merasa bahwa pasangannya mendukung keputusannya dan mendukung pengembangan dirinnya. Sementara itu pada dimensi structure, seluruh berada pada kategori tinggi. Artinya, seluruh responden merasa bahwa pasangannya bersikap konsisten dan dapat dipercaya. 


\section{Journal of Psychological Science and Profesion (JPSP)}

Vol.2, No.1, April 2018

E-mail: jurnal.psp@unpad.ac.id

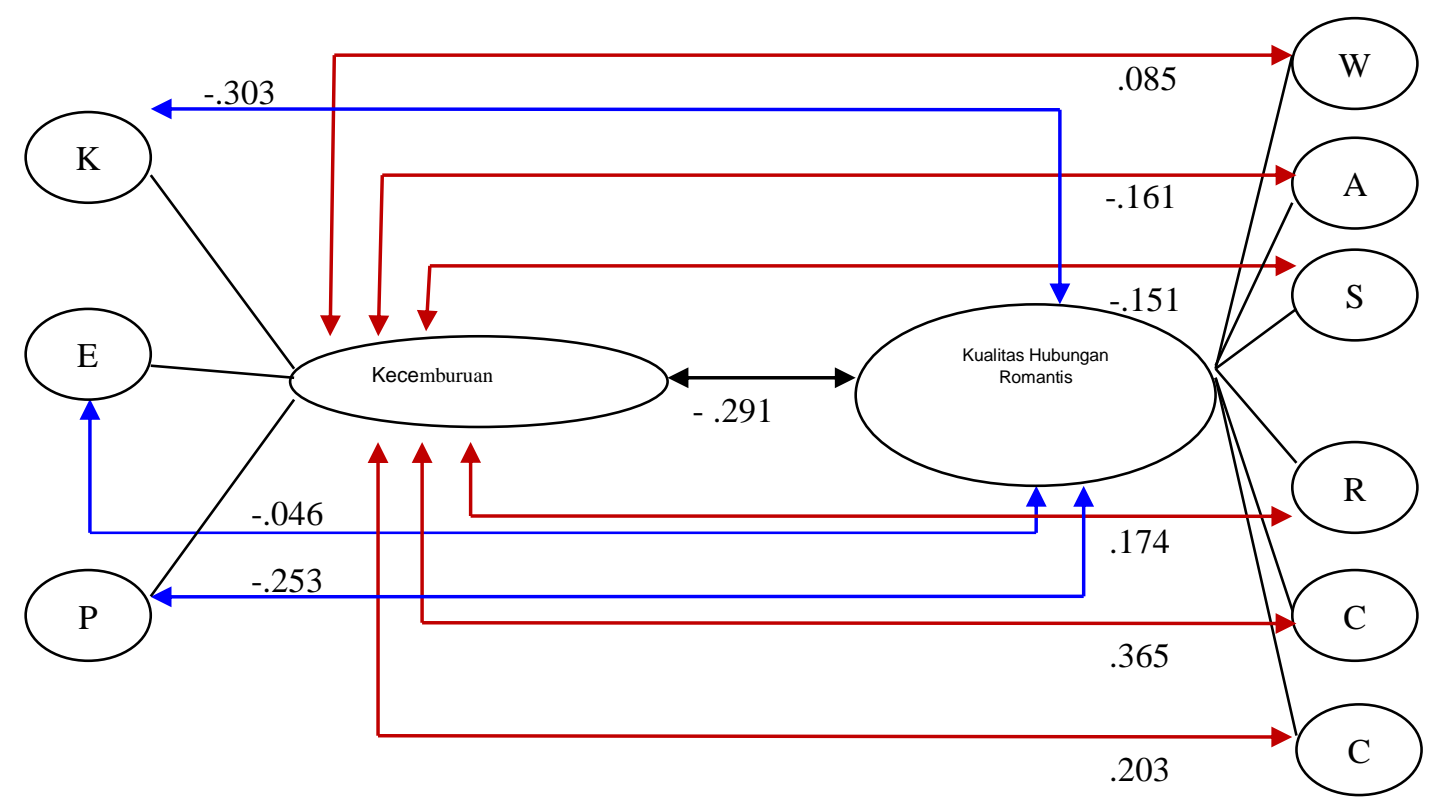

Gambar 2. Hasil Hubungan Kecemburuan dengan Kualitas Hubungan Romantis

\begin{tabular}{llll}
\multicolumn{2}{l}{ Keterangan } & \multicolumn{2}{l}{ Kualitas Hubungan Romantis } \\
Kecemburuan & W & : Warmth \\
K & : Kognitif & As & : Autonomy Support \\
E & : Emosi & S & : Structure \\
P & : Perilaku & R & : Rejection \\
& & C & : Coercion \\
& & Ch & $:$ Chaos
\end{tabular}

Berdasarkan analisa utama yang dilakukan hasilnya menunjukkan bahwa terdapat hubungan yang negatif antara kecemburuan dengan kualitas hubungan romantis, $r=-.291$, $p<0.01$. Nilai dari koefisien korelasi $(r)$ antara kedua variabel tersebut adalah sebesar -0.291 , yang berarti bahwa keduanya memiliki kekuatan hubungan yang rendah. Nilai korelasi yang berada antara 0,20-0,399 memiliki hubungan korelasi rendah (Sugiyono, 2007). Koefisien korelasi yang negatif menunjukkan bahwa kecemburuan dan kualitas hubungan romantis memiliki arah hubungan yang negatif, dimana semakin tinggi kecemburuan yang dimiliki oleh individu maka semakin rendah kualitas hubungan romantis yang dimiliki oleh individu tersebut.

Secara umum, kecemburuan diasosiasikan dengan hasil hubungan yang negatif, seperti konflik, kekerasan, dan perceraian (Barnett, Martinez, \& Bluestein, 1995; Buss, 2000; Puente \& Cohen, 2003 dalam Barelds \& Barelds-Dijkstra, 2007). Beberapa penulis berpendapat bahwa kecemburuan merupakan fenomena hubungan yang negatif dan dapat disertai dengan kualitas hubungan yang rendah. Kecemburuan tidak hanya berkontribusi pada konflik dan insecurity, tetapi juga menyebabkan pasangan non-jealous merasa tidak dipercaya dan dikontrol (Banfield \& McCabe, 2001; White, 1981 dalam Barelds \& Barelds-Dijkstra, 2007).

Komponen kecemburuan yang memiliki hubungan yang signifikan dengan kualitas hubungan romantis adalah komponen kognitif $(r=$ $-.303 / p=.002)$ dan perilaku $(r=-.253 / p=.008)$. Kedua komponen ini memiliki hubungan yang negatif signifikan dengan kualitas hubungan romantis. Nilai korelasi yang berada antara 0,20 0,399 memiliki hubungan korelasi rendah (Sugiyono, 2007). Dilihat dari koefisien korelasi kedua komponen tersebut maka dapat dikatakan keduanya memiliki korelasi yang rendah dengan kualitas hubungan romantis. Sementara untuk komponen emosi tidak terdapat hubungan yang signifikan dengan kualitas hubungan romantis.

Hal ini juga serupa dengan penelitian yang mengatakan bahwa komponen kognitif dan perilaku berhubungan negatif dengan kepuasan hubungan dan komitmen (Andersen, Eloy, 


\section{Journal of Psychological Science and Profesion (JPSP)}

Vol.2, No.1, April 2018

E-mail: jurnal.psp@unpad.ac.id

Guerrero, \&Spitzberg, 1995; Aylor \& Dainton, 2001; Bevan, 2008 dalam Rodriguez, et al., 2015). Sementara untuk komponen emosi menunjukkan hubungan yang tidak signifikan dengan kualitas hubungan romantis.

Komponen kognitif sendiri menekankan pada kekhawatiran dan kecurigaan yang paranoid seseorang akan ketidaksetiaan pasangannya (Pfeiffer \& Wong, 1989). Ini berarti semakin sering individu curiga dan khawatir akan ketidaksetiaan pasangnnya di instagram, maka semakin rendah kualitas hubungan romantisnya. Semakin sering individu memikirkan atau mencurigai pasangannya melakukan hal-hal yang menunjukkan ketidaksetiaan di instagram seperti berbalas direct message dengan perempuan atau laki-laki lain ataupun pasangannya tertarik dengan perempuan atau laki-laki lain di instagram, maka individu tersebut semakin tidak merasakan manfaat dari hubungan yang sedang ia jalan.

Salah satu contoh dari item yang mengukur komponen kognitif adalah "saya curiga pacar saya mungkin tertarik dengan laki-laki/perempuan lain di instagram". Semakin sering individu memikirkan bahwa pasangannya tertarik dengan laki-laki/perempuan lain di instagram maka semakin dirinya merasa bahwa hubungan yang sedang ia jalani tidak memberikan manfaat. Contoh lainnya adalah "saya berpikir pacar saya menggunakan instagram untuk lebih dekat dengan laki-laki/perempuan lain secara diamdiam", semakin sering remaja pengguna instagram memikirkan bahwa pasangannya menggunakan instagram untuk lebih dekat dengan laki-laki/perempuan lain secara diamdiam menunjukkan bahwa ia memiliki kecemburuan kognitif yang tinggi serta membuat kualitas hubungan romantisnya semakin rendah.

Selanjutnya komponen perilaku yang ditunjukkan dengan perilaku detektif atau protektif yang dilakukan seseorang ketika mempersepsikan adanya lawan, baik nyata ataupun tidak. Maka semakin sering individu melakukan perilaku detektif atau protektif, kualitas hubungannya akan semakin rendah. Perilaku detektif dan protektif ini dapat dipersepsikan sebagai perilaku yang mengontrol dan mengekang. Pada instagram hal ini bisa juga dilakukan. Beberapa fitur pada instagram dapat dimanfaatkan sebagai media untuk melakukan perilaku detektif dan protektif tersebut.

Perilaku ini bisa berupa memeriksa followers \& followings pasangan, bergabung saat pasangan sedang live, menanyakan keberadaan pasangan saat ia membuat snapgram, bisa juga dengan meminjam handphone pasangan secara tiba-tiba untuk melihat akitivitas pasangan di instgram. Hal ini serupa dengan dimensi coercion pada kualitas hubungan romantis. Coercion merupakan perilaku yang terlalu mengontrol pasangan, terlalu menuntut, dan memberikan tekanan kepada pasangan (Ducat \& ZimmerGembeck, 2010). Tingginya dimensi ini akan membuat kualitas hubungan romantis menjadi rendah. Ketika individu memiliki komponen perilaku dalam kecemburuan yang tinggi, hal tersebut dapat dipersepsikan menjadi coercion dan membuat kualitas hubungan romantisnya menjadi rendah.

Komponen emosi dalam kecemburuan tidak berhubungan secara signifikan dengan kualitas hubungan romantis. Komponen ini ditunjukkan misalnya dengan perasaan marah, ketakutan, atau sedih. Hal bisa terjadi karena adanya penilaian kognitif, tetapi juga bisa terjadi karena respon pada stimulus tertentu (Pfeiffer \& Wong, 1989). Hasil pada penelitian ini menunjukkan bahwa individu yang memiliki tingkat kecemburuan emosi yang tinggi belum tentu akan memiliki kualitas hubungan romantis yang rendah. Pada penelitian ini ditemukan bahwa individu yang memiliki kualitas hubungan romantis yang tinggi maupun rendah dapat merasakan kecemburuan emosi yang tinggi.

Selain itu hampir semua item pada komponen emosi diisi dengan jawaban "sangat kesal" oleh mayoritas responden. Responden melaporkan bahwa mereka sangat kesal ketika (1) pacar membuat instagram post yang menunjukkan ia sedang memeluk lakilaki/perempuan lain; (2) pacar selalu membalas komentar yang ditinggalkan laki-laki/perempuan lain pada instagram post miliknya; (3) pacar menuliskan nama laki-laki/perempuan lain pada bio-instagram. Komponen emosi memiliki ratarata skor yang paling tinggi serta tidak memiliki hubungan yang signifikan dengan kualitas hubungan romantis. Artinya baik responden yang memiliki kualitas hubungan romantis yang tinggi ataupun rendah akan merasa sangat kesal ketika pasangannya melakukan ketiga perilaku tersebut.

Pada variabel kualitas hubungan romantis terdapat dua dimensi yang memiliki hubungan signifikan dengan kecemburuan, yaitu dimensi chaos $(r=.203 / p=0.035)$ dan coercion $(r=.365 /$ $p=.000$ ). Koefisien korelasi dari dimensi chaos dan coercion yang bersifat positif menunjukkan arah hubungan yang positif. Keduanya merupakan dimensi negatif dari kualitas hubungan romantis. Pada penelitian ini ditemukan bahwa dimensi positif dari kualitas hubungan romantis tidak ada yang berhubungan secara signifikan dengan kecemburuan; kecemburuan berhubungan dengan dimensi negatif dari kualitas hubungan romantis. 


\section{Journal of Psychological Science and Profesion (JPSP)}

Vol.2, No.1, April 2018

E-mail: jurnal.psp@unpad.ac.id

Coercion didefinisikan sebagai tindakan terlalu mengontrol pasangan, terlalu menuntut, dan memberikan tekanan kepada pasangan. Hasil ini mengindikasikan bahwa semakin kuat perilaku mengontrol, menuntut, dan memberikan tekanan kepada pasangannya maka tingkat kecemburuan individu semakin tinggi. Dimensi chaos digambarkan dengan perilaku pasangan yang tidak konsisten, tidak menentu, dan tidak dapat dipercaya. Semakin sering individu maupun pasangan menunjukkan perilaku tidak konsisten dan tidak menentu maka semakin tinggi kecemburuan individu. Perilaku yang tidak konsisten dan tidak menentu dari pasangan ini dapat menimbulkan kecemburuan. Responden memberikan contoh hal yang menimbulkan kecemburuan misalnya ketika individu tidak pernah tahu apa yang selanjutnya akan dilakukan oleh pacarnya.

Peneliti melakukan analisis tambahan terkait kecemburuan dan kualitas hubungan romantis yang dikaitkan dengan data demografis yang sudah didapatkan. Data tersebut adalah usia, jenis kelamin, lama berpacaran, serta durasi mengakses instagram dalam satu hari. Peneliti melakukan perhitungan perbedaan skor rata-rata antara variabel kecemburuan dan kualitas hubungan romantis pada seluruh data demografis.

\section{Tabel 3. Perbedaan Rata-rata Kecemburuan pada Aspek Demografis Durasi Mengakses Instagram per Hari}

Tabel 4. Perbedaan Rata-rata Kualitas Hubungan Romantis pada Aspek Demografis Usia

\begin{tabular}{ccccc}
\hline Variabel & Usia & $\begin{array}{l}\text { Rata- } \\
\text { rata }\end{array}$ & F & $\boldsymbol{p}$ \\
\hline Kualitas & 15 & 238.67 & 3.129 & 0.029 \\
Hubungan & 16 & 249.66 & & \\
Romantis & 18 & 257.67 & & \\
& 18 & 238.39 & & \\
\hline
\end{tabular}

Selain itu, terdapat perbedaan skor ratarata kualitas hubungan romantis yang signifikan berdasarkan usia. Berdasarkan hasil perhitungan dapat dilihat bahwa yang memiliki rata-rata kualitas hubungan romantis paling tinggi adalah pada kelompok yang berusia 17 tahun. Kemudian yang rata-ratanya paling rendah adalah kelompok usia 15 tahun.

Menurut Ducat (2009) usia dapat dikatakan mempengaruhi penilaian kualitas hubungan romantis seseorang karena adanya asosiasi antara hubungan dan wellbeing diperkirakan akan berbeda sesuai dengan tugas perkembangan yang harus dicapai pada usia tertentu. Meskipun tugas perkembangan remaja usia 15,16,17, dan 18 tidak berbeda jauh, tetapi ternyata memiliki perbedaan pada kualitas hubungan romantisnya.

Tabel 5. Perbedaan Rata-rata Kualitas Hubungan Romantis pada Aspek Demografis Durasi Mengakses Instagram per Hari

\begin{tabular}{|c|c|c|c|c|c|c|c|c|c|}
\hline \multicolumn{5}{|c|}{$\begin{array}{l}\text { pada Aspek Uemogratis UurasI IVIengakses } \\
\text { Instagram per Hari }\end{array}$} & Variabel & Durasi & Rata-rata & $\mathbf{F}$ & $p$ \\
\hline Variabel & Durasi & Rata-rata & $\mathbf{F}$ & $p$ & \multirow{3}{*}{ Kecemburuan } & $\leq 3$ jam & 254.19 & 3.648 & 0.029 \\
\hline \multirow{3}{*}{ Kecemburu } & & & & & & 4-7 jam & 235.29 & & \\
\hline & $\leq 3$ jam & 116.37 & 5.775 & 0.004 & & $>7$ jam & 238.88 & & \\
\hline & $>7 \mathrm{jam}$ & 12514 & & & & & & & \\
\hline
\end{tabular}

Hasilnya adalah terdapat perbedaan skor rata-rata kecemburuan yang signifikan antara responden yang mengakses instagram $\leq 3$ jam/hari, 4-7 jam/hari, dan > 7 jam/hari. Kelompok yang memiliki rata-rata skor kecemburuan paling tinggi adalah yang durasi mengakses instagram per harinya 4-7 jam. Sementara responden yang mengakses Instagram $\leq 3$ jam per harinya memiliki kecemburuan yang paling rendah.
Selanjutnya untuk perbedaan skor rata-rata kualitas hubungan romantis berdasarkan durasi mengakses instagram per hari hasilnya adalah terdapat perbedaan skor rata-rata kualitas hubungan romantis yang signifikan berdasarkan durasi mengakses instagram per hari. Terlihat bahwa yang memiliki rata-rata skor kualitas hubungan romantis paling tinggi adalah kelompok yang mengakses instagram $\leq 3$ jam dan yang terendah adalah yang mengakses instagram selama 4-7 jam per hari. Sementara untuk jenis kelamin dan lama berpacaran tidak terdapat perbedaan skor rata-rata yang signifikan pada kedua variabel.

Pada penelitian ini juga ditemukan hal baru yaitu responden yang mengakses instagram 4-7 jam/hari memiliki skor rata-rata kecemburuan yang paling tinggi terutama pada komponen 


\section{Journal of Psychological Science and Profesion (JPSP)}

Vol.2, No.1, April 2018

E-mail: jurnal.psp@unpad.ac.id

emosi dan perilaku serta skor rata-rata kualitas hubungan romantis yang paling rendah. Pada penelitian ini tidak dapat dilihat secara pasti mengapa responden yang mengakses instagram 4-7 jam/hari yang memiliki skor rata-rata kecemburuan yang paling tinggi dan skor ratarata kualitas hubungan romantis yang paling rendah. Hal ini karena pada penelitian ini tidak terdapat data terperinci mengenai aktivitas dan informasi apa saja yang didapatkan oleh responden pada saat mengakses instagram.

\section{SIMPULAN}

Berdasarkan hasil dari penelitian ini, maka dapat disimpulkan beberapa hal, yaitu terdapat hubungan antara kecemburuan dengan kualitas hubungan romantis yang negatif secara signifikan pada remaja pengguna instagram usia 15-18 tahun yang berpacaran. Hubungan yang negatif secara signifikan menunjukkan bahwa semakin tinggi kecemburuan yang dimiliki oleh individu, maka semakin rendah kualitas hubungan romantis yang ia miliki. Jika dilihat secara lebih spesifik, maka komponen kognitif dan komponen perilaku dari kecemburuan memiliki hubungan yang negatif signifikan dengan kualitas hubungan romantis. Sementara komponen emosi tidak berhubungan secara signifikan dengan kualitas hubungan romantis.

Selanjutnya ditinjau dari dimensi-dimensi
kualitas hubungan romantis dengan kecemburuan. Dari keenam dimensi dari kualitas hubungan romantis, yaitu autonomy support, warmth, structure, chaos, rejection, dan coercion yang memiliki hubungan yang signifikan dengan kecemburuan hanyalah dimensi chaos dan coercion. Kedua dimensi ini memiliki hubungan yang positif dan signifikan dengan kecemburuan.

Penelitian ini juga menunjukkan bahwa responden dengan usia yang berbeda memiliki tingkat kualitas hubungan romantis yang berbeda. Responden dengan durasi mengakses Instagram dalam sehari yang berbeda juga memiliki tingkat kecemburuan dan kualitas hubungan romantis yang berbeda pula.

Selain itu juga disimpulkan bahwa responden yang mengakses instagram 4-7 jam/hari memiliki skor rata-rata kecemburuan yang paling tinggi terutama pada komponen emosi dan perilaku serta skor rata-rata kualitas hubungan romantis yang paling rendah. Berdasarkan hasil penelitian ini disarankan untuk para remaja yang sedang berpacaran sebaiknya tidak terlalu sering memikirkan atau mencurigai pasangannya menjadi tidak setia di instagram dan tidak terlalu sering melakukan perilaku detektif atau protektif kepada pasangannya melalui instagram.

\section{SARAN}

Penelitian ini masih memiliki kekurangan serta keterbatasan sehingga untuk peneliti selanjutnya dapat mempertimbangakan saran berikut ini:

1. Pada penelitian ini, responden berada pada rentang usia 15-18 tahun, namun proposi dari masing-masing usia berbeda jauh. Maka dari itu, diharapkan penelitian selanjutnya untuk lebih mempertimbangkan aspek persebaran usia dari responden peneltian. Selain itu juga penelitian selanjutnya dapat dilakukan pada rentang usia atau tahap perkembangan yang lain.

2. Penelitian ini menggunakan metode korelasional sehingga belum dapat dilihat variabel mana yang lebih memengaruhi variabel lain. Oleh karena itu, dapat dicoba untuk peneliti selanjutnya melakukan analisis regresi terkait dengan kedua variabel ini agar mendapat gambaran yang lebih jelas.

3. Pada penelitian ini didapatkan hasil bahwa individu yang mengakses Instagram 4-7 jam/hari lah yang memiliki kecemburuan yang paling tinggi dan kualitas hubungan romantis yang paling rendah. Namun, dari penelitian ini tidak dapat menjelaskan faktorfaktor penyebabnya. Sehingga untuk peneliti selanjutnya dapat melihat secara lebih lanjut mengenai durasi, aktivitas serta informasi yang didapatkan individu ketika mengakses Instagram dalam waktu tersebut.

\section{DAFTAR PUSTAKA}

Andersen, P.A., Eloy, S.V., Guerrero, L.K., \& Spitzberg, B.H. (1995). Romantic jealousy and relational satisfaction: A look at the impact of jealousy experience and expression. Communication Reports, 8, 77-85.

Barelds, D. P., \& Barelds-Dijkstra, P. (2007). Relations between different types of jealousy and self and partner perceptions of relationship quality. Clinical Psychology \& Psychotherapy, 14(3), 176-188.

Barnett, O.W., Martinez, T.E., \& Bluestein, B. (1995). Jealousy and romantic attachment in maritally violent and nonviolent men. Journal of Interpersonal Violence, 10, 473486.

Buunk, B.P. (1991). Jealousy in close relationships: An exchange theoretical perspective. In P. Salovey (Ed.), 


\section{Journal of Psychological Science and Profesion (JPSP)}

Vol.2, No.1, April 2018

E-mail: jurnal.psp@unpad.ac.id

Psychological perspectives on jealousy and envy (pp.

148-177). New York: Guilford Publications.

Christensen, L. B., \& Waraczynski, M. A. (1988). Experimental methodology. Boston: Allyn and Bacon.

Collins, W.A. (2003). More than Myth : The Developmental Significance of Romantic Relationships During Adolescence. Journal of Research on Adolescence, 13(1), 1-24.

Ducat, W. H. (2009). Self and Partner Qualities in Emerging Adults' Heterosexual Romantic Relationships: A Self-Determination Approach to Individual Well-Being (Doctoral dissertation, Griffith University).

Ducat, W. H., \& Zimmer-Gembeck, M. J. (2010). Romantic partner behaviours as social context: Measuring six dimensions of relationships. Journal of Relationships Research, 1(1), 1-16.

Farrugia, R. C. (2013). Facebook and relationships: A study of how social media use is affecting long-term relationships. Rochester Institute of Technology.

Hasyim, Sarrah (2015). Hubungan antara Romantic Self-Efficacy dan Kualitas Hubungan Romantis pada Dewasa Muda yang Berpacaran Jarak Jauh. Depok: Fakultas Psikologi Universitas Indonesia

Scanlan, F., Bailey, A., \& Parker, A. (2012). Evidence Summary: Adolescent Romantic Relationships-Why are they important? And should they be encouraged or avoided.

MASTEL \& APJII. (2017). Press Release Survey Ekosisten DNA (Device, Network \& Application. Diakses pada 13 April 2017 dari www.mastel.id

Monks, F. J., Knoers, A. M. P., \& Haditono, S. R. (2002).

Psikologi perkembangan. Pengantar Dalam Berbagai Bagiannya, Terjemahan Sri Rahayu Haditomo, Yogyakarta: UGM.

Muise, A., Christofides, E., \& Desmarais, S. (2009). More information than you ever wanted: Does Facebook bring out the green-eyed monster of jealousy?. CyberPsychology \& behavior, 12(4), 441-444.

Pfeiffer, S. M., \& Wong, P. T. (1989). Multidimensional jealousy. Journal of Social and Personal Relationships, 6(2), 181-196.

Rodriguez, L. M., Dibello, A. M., Øverup, C. S., \& Neighbors, C. (2015). The price of distrust: trust, anxious attachment, jealousy, and partner abuse. Partner abuse, 6(3), 298.

Shackelford, T.K., \& Buss, D.M. (2000). Marital satisfaction and spousal cost-infliction. Personality and Individual Differences, (28), 917-928.
Sugiyono, M. P. P. P. K. (2007). Kualitataif dan R\&D, Bandung: Alfabeta, 2010. Sugiyono, Metode Penelitian Kuantitatif kualitatif dan $R \& D$ Bandung: Alfabeta.

Utz, S., \& Beukeboom, C.J. (2011). The Role of Social Network Sites in Romantic Relationship : Effects on Jealousy and Relationship Happiness. Journal of Computer-Mediated Communication, 16, 511-527

Utz, S., Muscanell, N., \& Khalid, C. (2015). Snapchat elicits more jealousy than Facebook: A comparison of Snapchat and Facebook use. Cyberpsychology, Behavior, and Social Networking, 18(3), 141-146.

White, G.L. (1980). Inducing Jealousy: A Power Perspective. Personality and Social Psychology Bulletin, 6(2): 222-227

Winarso, B. (2015). Apa itu Instagram, Fitur dan Cara Menggunakannya?. DailySocial. id, 18. 